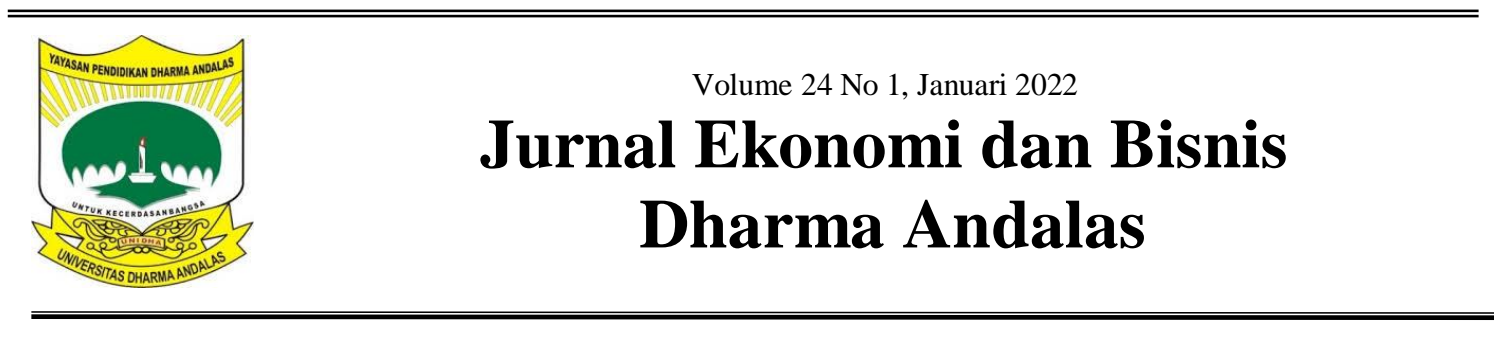

\title{
Self Confidence dan Courage To Take Risks Mempengaruhi Keberhasilan UMKM Rendang Kota Payakumbuh
}

\author{
Eka Mariyanti ${ }^{1}$, Hendro Saputra ${ }^{2}$, Siska Lusia Putri ${ }^{3}$, Puti Embun Sari ${ }^{4}$ \\ Fakultas Ekonomi Ekonomi dan Bisnis, Universitas Dharma Andalas Padang 1,2,3,4 \\ email: ekamariyanti@unidha.ac.id ${ }^{1}$ \\ siskalusiaputri@gmail.com ${ }^{3}$ \\ putimbun@gmail.com ${ }^{4}$
}

\begin{abstract}
The purpose of this paper is to to identify Self Confidence and Courage to Take Risks and their relationship to the success of UMKM engaged in gastronomy, especially Rendang in the city of Payakumbuh, West Sumatra. This research was conducted on all UMKM owners of rendang culinary who are members of the Iko Sero Payakumbuh Cooperative, totaling 43 business actors who are registered as members of the cooperative until 2021. The data collected was analyzed using the SPSS 21 program which provides relevant analyzes such as analysis of validity, reliability and regression analysis. Three hypotheses were developed to study the effect of Self Confidence and Courage to Take Risks on the success of Rendang UMKM in Payakumbuh City. Through correlation analysis, Self Confidence and Courage to Take Risks in the gastronomic field were observed to have a significant influence on the success of the Rendang UMKM. All key variables have a significant relationship with the success of SMEs. The results of the regression analysis showed that the most significant independent variable affecting the success of the Rendang UMKM business in Payakumbuh City was Self Confidence

Keyword : Self Confidence, Courage to Take Risks, success of UMKM, Gastronomi, and Rendang
\end{abstract}

\begin{abstract}
ABSTRAK
Penelitian ini bertujuan untuk mengidentifikasi Self Confidence dan Courage to Take Risks dan hubungannya dengan keberhasilan UMKM yang bergerak pada bidang gastronomi khususnya rendang di kota Payakumbuh, Sumatera Barat. Penelitian ini dilakukan pada seluruh UMKM Pemilik Usaha kuliner rendang yang tergabung di Koperasi Iko Sero Payakumbuh yang berjumlah 43 pelaku usaha yang terdaftar sebagai anggota koperasi sampai tahun 2021. Data yang terkumpul dianalisis dengan menggunakan program SPSS 21 untuk dilakukan analisis validitas, Reliabilitas dan analisis regresi. Tiga hipotesis dikembangkan untuk mempelajari pengaruh Self Confidence dan Courage to Take Risks terhadap keberhasilan UMKM rendang di Kota Payakumbuh. Melalui analisis korelasi, Self Confidence dan Courage to Take Risks pada bidang gastronomi yang diamati memiliki pengaruh yang signifikan dengan keberhasilan UMKM Rendang tersebut. Semua variabel kunci memiliki hubungan yang signifikan dengan keberhasilan UMKM. Hasil analisis regresi menunjukkan bahwa variable independen yang paling signifikan mempengaruhi keberhasilan bisnis UMKM rendang di Kota Payakumbuh adalah Self Confidence.
\end{abstract}

Kata Kunci: Self Confidence, Courage to Take Risks, Keberhasilan UMKM, Gastronomi, dan Rendang 


\section{PENDAHULUAN}

\section{Gastronomi dan pariwisata
merupakan bidang ilmu yang} multidisiplin dan "budaya" merupakan kata kunci untuk menghubungkan keduanya. Gastronomi menjelaskan komponen-komponen budaya, seperti sejarah, tradisi, sistem kepercayaan, serta cerita-cerita rakyat yang berkembang dalam masyarakat Ranah Minang dengan makanan sebagai pusat kajiannya. Gastronomi menganggap makanan sebagai produk budaya dari kelompok masyarakat tertentu. Seperti halnya arsitektur, bahasa, musik, kriya, dan seni pertunjukan, makanan juga bisa menjadi identitas budaya lokal. Di sisi lain budaya adalah salah satu komponen daya tarik wisata. Banyak orang berwisata dengan tujuan untuk menikmati orisinalitas budaya setempat. Sementara itu, pariwisata memberikan kesempatan yang luas pada stakeholder di suatu wilayah atau destinasi untuk menyediakan segala kebutuhan wisatawan. Kebutuhan untuk menikmati lansekap dan budaya yang unik, akomodasi, transportasi, dan tentu saja makanan. Kebutuhan akan makanan menyediakan dua pilihan bagi wisatawan, yakni makanan lokal atau makanan umum yang tidak ada kaitannya dengan budaya lokal. Makanan lokal adalah bagian dari gastronomi yang mempunyai kekuatan "behind the scene" dari penciptaan makanan tersebut. Ada cerita sejarah dan tradisi yang mengiringinya. Menikmati makanan lokal yang dikemas dengan cerita (storytelling) yang menarik, adalah sebuah atraksi gastronomi.

Menurut Hjalager dan Richards (2003) bahwa gastronomi memberikan nilai tambah pada pariwisata dengan menghubungkan budaya, lansekap, dan makanan lokal menjadi sebuah pengalaman berwisata yang tak terlupakan. Sementara itu, pariwisata menawarkan kesempatan kepada produsen makanan untuk menambah nilai produknya melalui pengalaman wisatawan pada proses produksi dan konsumsi makanan tersebut. Baik gastronomi maupun pariwisata, masingmasing memberikan nilai tambah melalui pengalaman. Keduanya mempunyai produk tangible (berwujud/benda), seperti lansekap, seni, dan makanan, namun yang sebenarnya dijual adalah unsur intangible (tak berwujud/non-benda), yaitu pengalaman.

Dalam perjalanan dan aktivitas wisata, makanan adalah pusat pengalaman karena wisatawan akan selalu butuh makan di mana pun mereka berada. Globalisasi makanan menjadi semacam halangan bagi gastronomi untuk ikut berperan pada sebuah destinasi. Gastronomi menjadi kurang berarti ketika wisatawan memutuskan untuk tidak menikmati makanan lokal dan lebih memilih comfort food yang tidak jauh dari makanan mereka seharihari. Walaupun di sisi lain, globalisasi makanan juga memberikan kesempatan terhadap makanan lokal untuk bisa lebih dikenal di seluruh dunia. Namun, butuh kekuatan yang besar untuk menjadi bagian dari makanan global. Saat ini globalisasi makanan identik dengan menjamurnya merek fastfood, seperti McDonald, Kentucky Fried Chicken, Burger King, dan lainnya. Ketika namanama fastfood tersebut ada pada sebuah destinasi, ini akan menjadi tantangan yang berat bagi makanan lokal untuk bersaing.

Hal lain yang terkait dengan pengembangan gastronomi maupun pariwisata dan UMKM, adalah aspek higienitas atau kebersihan sebagai isu utama. Bagi kebanyakan wisatawan, nama-nama fastfood tersebut memberikan jaminan harga yang lebih 
jelas, produksi yang lebih higienis, dan kualitas yang lebih terstandar. Mereka tidak mau mengambil risiko dengan makanan lokal yang belum mereka kenal sebelumnya. Atau, bisa jadi mereka tidak mendapatkan informasi yang baik tentang makanan lokal yang tersedia. Maka, gastronomi juga menjadi daya tarik wisata yang paling rentan untuk tidak dipilih oleh wisatawan dibandingkan dengan daya tarik wisata lain, seperti lanskap dan atraksi budaya.

Namun, jika makanan lokal dibuat dengan kebersihan standar tinggi, dikemas dengan tampilan yang menarik, diiringi dengan aktivitas dan cerita atraktif, dan dipromosikan bersama atraksi lain untuk mendukung sebuah destinasi, tentu akan menjadi sebuah kekuatan bagi gastronomi untuk bersaing dengan makanan-makanan produk dari globalisasi. Kolaborasi gastronomi dan pariwisata kian memberikan manfaat nyata kepada para pihak terkait, terutama masyarakat lokal.

Gastronomi memberikan nilai tambah bagi destinasi melalui pengalaman berwisata, sementara pariwisata ikut berperan dalam menjaga keberlangsungan makanan lokal. Selain itu, sebagai suatu bentuk kolaborasi yang ideal, pariwisata juga membantu meningkatkan pendapatan masyarakat lokal melalui pengembangan gastronomi di waktu yang bersamaan.

Kota Payakumbuh sebagai Kawasan Strategi Pariwisata Provinsi dalam Rencana Induk pembangunan kepariwisataan Provinsi (RIPKP) Sumatera Barat telah menjadi tujuan perjalanan wisatawan nusantara dan mancanegara selama ini ke wilayah Sumatera Barat. Kota Payakumbuh telah menjadi salah satu destinasi bagi wisatawan nusantara maupun mancanegara dari pintu masuk Pekanbaru, Medan dan Kota Padang sendiri.
Visi kota payakumbuh dalam Rencana induk Pembangunan Pariwisata (RIPK) Kota Payakumbuh adalah "Terwujudnya Payakumbuh sebagai Kota GASTROWISATA yang berdaya saing dan berwawasan alam dan budaya".

Industri pariwisata Kota Payakumbuh dan sektor-sektor usaha turunannya didominasi oleh pelaku UMKM. Memang terdapat usaha yang digolongkan usaha besar di Kota Payakumbuh, namun jumlahnya amat kecil dan statusnya sebagian besar merupakan cabang usaha besar dan perusahaan multinasional yang pusatnya tidak berada di Kota Payakumbuh. Dapat dikatakan bahwa perekonomian Kota Payakumbuh amat bersandar pada keberadaan UMKM ini.

Capaian indikator persentase Usaha Kecil Menengah diperoleh dari tumbuh kembangnya Usaha Kecil Menengah yang terlihat dari peningkatan skala usahanya. Usaha Mikro memiliki kekayaan sampai dengan 50 Juta, Usaha Kecil memiliki kekayaan 50 juta s.d 500 juta dan Usaha Menengah memiliki kekayaan diatas 500 juta. Indikator sasaran persentase Usaha Kecil Menengah terhadap "UMKM", target tahun 2018 adalah $27,64 \%$ dan realisasi adalah $15,27 \%$ dengan capaian 55,25\% .

\section{Tabel 1}

Perkembangan Jumlah Usaha di Kota Payakumbuh tahun 2014-2018

\begin{tabular}{|c|c|c|c|c|c|c|}
\hline Jenis usaha & Satuan & 2014 & 2015 & 2016 & 2017 & 2018 \\
\hline Usaha Mikro & Unit & 14.935 & 15.084 & 15.235 & 15.262 & 216.714 \\
\hline Usaha Kecil & Unit & 5.217 & 5.269 & 5.322 & 5.471 & $1 \quad 2.565$ \\
\hline $\begin{array}{l}\text { Usaha } \\
\text { Menengah-Besar }\end{array}$ & Unit & 207 & 209 & 211 & 214 & 448 \\
\hline Total UMKM & Unit & 20.359 & 20.562 & 20.678 & 20.947 & 19.727 \\
\hline $\begin{array}{l}\text { Persentase UKM } \\
\text { terhadap } \\
\text { UMKM }\end{array}$ & $\%$ & 26,64 & 26,64 & 26,64 & 27,14 & 15,27 \\
\hline
\end{tabular}

Sumber data : Dinas Koperasi UKM, 2018

Berdasarkan tabel di atas dapat 
dilihat persentase Usaha Kecil Menengah terhadap UMKM pada tahun 2018 menurun bila dibandingkan dengan tahun-tahun sebelumnya. Sebagaimana dengan daerah lainnya di Indonesia, UMKM Kota Payakumbuh merupakan pelaku usaha yang menyerap tenaga kerja terbesar, memberikan kontribusi terhadap PDRB, sumber inovasi daerah, menekan laju inflasi dan mampu berperan dalam pemerataan kesejahteraan.

Namun demikian, UMKM

Kota Payakumbuh juga patut diperhatikan terkait dengan situasi dan kondisi yang dihadapinya.

Selain itu, sudah saatnya industri pariwisata Kota Payakumbuh memberikan prioritas yang lebih besar terhadap perkembangan sektor ekonomi kreatif yang dapat turut menjadi tulang punggung industri pariwisata. Kota Payakumbuh dinilai telah memiliki modal yang cukup untuk itu karena sudah memiliki UMKM yang secara tradisional amat berhubungan erat dengan sektor ekonomi kreatif, seperti produk fashion, kriya dan kuliner. Pengembangan sektor industri kreatif di Kota Payakumbuh diyakini akan dapat menjadi primadona baru dalam industri pariwisata Payakumbuh karena diberbagai destinasi wisata manapun diseluruh dunia, wisatawan akan selalu tertarik dengan kreativitas yang ditampilkan oleh masyarakat lokal. Tambahan lagi, Badan Ekonomi Kreatif Nasional (BEKRAF) juga sudah meminta agar masing-masing kota dan kabupaten di Indonesia untuk menetapkan satu sektor ekonomi kreatif unggulan yang akan dipromosikan secara lebih luas dalam skala nasional maupun internasional. Ini tentunya akan menjadi peluang tersendiri bagi pelaku usaha industri pariwisata Kota Payakumbuh, dengan jalan mengemas sektor ekonomi kreatif tersebut sedemikian rupa sehingga wisatawan akan tertarik untuk menikmatinya.

Hal lain yang mungkin masih perlu diperhatikan dengan serius oleh Pemerintah Kota Payakumbuh adalah fasilitas gallery bersama yang dapat menampung aktivitas pelaku ekonomi kreatif Kota Payakumbuh untuk berkarya dan memasarkan produk karya yang dihasilkannya. Hal ini tentunya butuh komitmen dari pemerintah Kota Payakumbuh agar industri pariwisata Kota Payakumbuh dapat menawarkan usaha yang lebih beragam kepada para wisatawan yang berkunjung ke Kota Payakumbuh.Untuk mengakomodasi kekuatan ini maka positioning sebagai kota Gastrowisata diperkirakan sesuai dengan kondisi real kota ini.

Berdasarkan data dari Badan Pusat Statistik Kota Payakumbuh jumlah UMKM di Kota Payakumbuh pada tahun 2020 tercatat sebanyak 461 UMKM formal dan non formal. Selain itu Kota Payakumbuh dikenal dengan berbagai kuliner khas, seperti sate danguangdanguang, minuman kawa daun (daun kopi seduh), ampiah dadiah (sejenis yogurt dari susu sapi) dan yang sudah mendunia adalah randang. Rendang menduduki peringkat pertama sebagai makanan terenak di dunia dalam World's 50 Most Delicious Foods (CNN, 2011). Selama delapan kali berturut-turut, randang bertahan pada peringkat pertama hingga tahun 2019. Tahun 2018 lalu, randang secara resmi ditetapkan sebagai salah satu dari lima kuliner nasional Indonesia. Hal ini menjadi peluang besar bagi pemerintah Kota Payakumbuh untuk mengembangkan rendang ke berbagai negara. Seperti yang telah dilakukan pada tahun 2019, Pemerintah Kota Payakumbuh melakukan promosi produk rendang dengan mengikuti pameran produk haji dan umrah di Komjen RI Jeddah, Arab. 
Randang menurut Azima \& Sayuti, (2016) terkenal sebagai masakan yang memiliki cita rasa yang khas, dikarenakan dalam pembuatannya menggunakan berbagai macam bumbu dan rempah-rempah. Sehingga hal ini yang membuat pemerintah Kota Payakumbuh menggencarkan gastronomi untuk menjajakan makanan khas Payakumbuh. Sehingga citra makanan yang dimiliki randang mampu menarik minat banyak wisatawan dalam maupun luar negeri untuk mengunjungi kembali kota ini hanya sekedar untuk menikmati gastrowisata

Selain sentral Rendang yang menjadi pusat industry pengolahan rendang dipayakumbuh juga terdapat Salah satu Koperasi yang manaungi sebagian UMKM di Kota Payakumbuh yang bergerak pada sector makanan khusus masakan rendang yaitu Koperasi Iko Sero Payakumbuh, hingga saat ini koperasi ini menaungi sebanyak 43 UMKM. Oleh karena itu pemilik usaha masakan rendang yang tergabung dalam koperasi ini harus memiliki self confidence atas kemampuannya untuk dapat menghasilkan masakan yang dapat memenuhi selera pasar dan juga Courage to take risks yang kuat untuk bekerja keras dan bertahan dalam persaingan pasar yang semakin kompetitif.

Berdasarkan survey awal dan pengumpulan data yang diperoleh dari pemilik usaha di Koperasi Iko Sero Payakumbuh, dapat diketahui jumlah pemilik usaha di Koperasi Iko Sero

Tabel 2

Jumlah Pemilik Usaha di Koperasi Iko Sero Payakumbuh

\begin{tabular}{ccc}
\hline No & Tahun & Jumlah Pemilik Usaha \\
\hline 1 & 2019 & 71 \\
2 & 2020 & 58 \\
3 & 2021 & 43 \\
\hline Sumber: & Hasil survey lapangan 2021
\end{tabular}

Berdasarkan data pada table 2 diatas dapat disimpulkan bahwa Koperasi Iko Sero Payakumbuh mengalami penurunan jumlah pemilik usaha yang diakibatkan oleh beberapa faktor. Berdasarkan hasil wawancara yang dilakukan dengan Manajemen koperasi Iko Sero terdapat beberapa upaya yang dilakukan oleh Koperasi Iko Sero Payakumbuh untuk mencapai keberhasilan usaha yang dijalankan terdapat beberapa masalah dalam segi perilaku kewirausahaan, hal ini ditandai bahwa beberapa pelaku UMKM rendang merasa kurangnya self confidence $\mathrm{i}$ karena mereka merasa ada ketakutan dan pesimis dengan produk yang mereka hasilkan karena terlalu banyak competitor dibidang usaha ini serta tidak semua UMKM di industry ini siap untuk mengambil resiko dengan kondisi pandemic saat ini. Berkaitan dengan keberanian mengambil risiko, hasil penelitian Garaika, Margahana, \& Negara, (2019) menyimpulkan bahwa aspek keberanian menghadapi risiko berpengaruh signifikan dan memiliki hubungan positif terhadap keberhasilan suatu usaha. Senada dengan penelitian ini, Fatoki (2018) juga menyimpulkan bahwa keberanian menghadapi risiko berpengaruh positif terhadap keberhasilan pelaku UKM. Berdasarkan hasil penelitian tersebut, dapat disimpulkan bahwa keberlangsungan suatu usaha juga ditentukan oleh keberanian wirausahawan dalam menghadapi risiko. Semakin berani seorang pelaku usaha dalam menghadapi risiko, semakin besar kemungkinan kinerja dan keberlanjutan usaha dapat dicapai. Suryana (2017) berpendapat bahwa pengambilan risiko berkaitan dengan kepercayaan diri. Dia menambahkan bahwa semakin besar kepercayaan seseorang pada kemampuannya sendiri, semakin besar 
kepercayaan orang tersebut pada kemampuannya untuk mempengaruhi hasil dan keputusan, dan semakin besar kemauan orang tersebut untuk melakukan apa yang orang lain anggap sebagai risiko.

Secara umum, tujuan dari penelitian ini adalah untuk melihat pengaruh self confidence dan Courage to Take Risks mempengaruhi keberhasilan UMKM Pemilik Usaha kuliner rendang yang tergabung di Koperasi Iko Sero Payakumbuh.

\section{Self Confidence}

Menurut Hidayat (2016) Kepercayaan diri (self confidence) sangat lah penting bagi keberhasilan hidup seseorang di karenakan perasaan ini merupakan keyakinan pada kemampuan dan penilaian diri sendiri dalam melakukan suatu tugas dan memilih pendekatan yang efektif, termasuk juga kepercayaan atas kemampuan mengahadapi lingkungan yang semakin menantang dan kepercayaan atas keputusan atau pendapat nya, Kepercayaan diri juga diperoleh dari pengalaman hidup seseorang. Hakim (2016) kepercayaan diri adalah suatu keyakinan seseorang terhadap segala aspek kelebihan yang dimiliki dan keyakinan tersebut membuatnya merasa akanmampu mencapai tujuan tertentu dalam hidupnya. Kepercayaan diri adalah keyakinan seseorang yang mampu berperilaku sesuai dengan yang di harapkan dan diinginkan (Yusuf, 2020). Menurut Jadmiko, Azliyanti, \& Putri, (2019) self confidence juga adalah keyakinan akan kemampuan diri sendiri, keyakinan adanya suatu maksud di dalam kehidupan, dan harapan dengan berfikir.

Kepercayaan diri merupakan engsel pintu gerbang prestasi, ketika kepercayaan diri seseorang tak terbatas, maka seseorang mampumewujudkan lebih banyak potensi ketimbang dalam kondisi berbeda (Tracy, 2016). Menurut Willis (2017) kepercayaan diri adalah suatu keyakinan bahwa seseorang mampu menyelesaikan suatu masalah dengan situasi terbaik dan dapat memberikan sesuatu yang menyenangkan bagi orang sekitar. Sedangkan menurut Júnior, Spers, de Lima, da Costa Simões, \& Neves, (2021). mendefinisikan bahwa kepercayaan diri di peroleh dari pengalaman hidup dan menambahkan bahwa kepercayaan diri berhubungan dengan kemampuan melakukan sesuatu yang baik. Anthony (2017) berpendapat bahwa kepercayaan diri merupakan sikap seseorang yang dapat menerima kenyataan, dapat mengembangkan kesadaran diri, berpikir positif, memiliki kemandirian, dan mempunyai kemampuan untuk memiliki serta mencapai segala sesuatu yang diinginkan. Menurut Otache, (2020). menyatakan bahwa kepercayaan diri merupakan suatu ciri dari kepribadian yang mengandung arti keyakinan terhadap kemampuan diri sendiri. Kepercayaan diri merupakan sikap mental seseorang dalam menilai diri maupun suatu objek di sekitarnya sehingga seseorang tersebut mempunyai keyakinan akan kemampuan dirinya untuk dapat melakukan sesuatu sesuai kemampuan yang dimiliki (Gufron, 2017). Kepercayaan diri dapat langsung datang ketika berperilaku dengan penuh rasa self confidence, tetapi terkadang lebih sering datang secara tidak langsung, seperti saat seseorang melakukan, mengucapkan, serta menerapkan sikap yang mengarah pada kepercayaan diri (Tracy, 2016).

\section{Courage To Take Risks}

sMenurut Ahmad, Musa, Widhi, \& Tahmir, (2018) dan Kozubíková, Dvorský, Cepel, \& Balcerzak, (2017). Keberanian mengambil risiko dalam 
wirausaha adalah suatu keinginan untuk mencoba melakukan secara cerdas terlepas dari rasa malu dan takut. Seorang wirausaha harus berani bertanggung jawab, bersedia menguji coba dugaannya tentang usaha yang akan dijalankan dan berani mengambil risiko salah.

\section{Keberhasilan Usaha}

$$
\text { Menurut Ranto }
$$

Keberhasilan berwirausaha tidaklah identik dengan seberapa berhasil seseorang mengumpulkan uang atau harta serta menjadi kaya, karena kekayaan bisa diperoleh dengan berbagai cara sehingga menghasilkan nilai tambah. Berusaha lebih dilihat dari bagaimana seseorang bisa membentuk, mendirikan, serta menjalankan usaha dari sesuatu yang tadinya tidak berbentuk, tidak berjalan atau mungkin tidak ada sama sekali.

Furue, Aziz, Mori, Hermawan, A., Assarut, Uehara, \& Washida, (2020). menjelaskan bahwa Pengusaha sukses juga harus memiliki self confidence. Nilai ini menjadi landasan bagi pengusaha untuk melakukan aktivitas apapun dan menyelesaikannya dengan bijak. Pengusaha hendaknya memiliki keberanian dan kepercayaan diri yang tinggi untuk maju dalam bisnis. Hal ini telah difirmankan oleh Allah SWT melalui firman-Nya yang artinya: "Dan janganlah kamu lemah, dan jangan bersedih hati, dan kamu akan berada di atas angin jika kamu orang-orang yang beriman" Surah al-Imran (3): 139.

\section{Framework Penelitian}

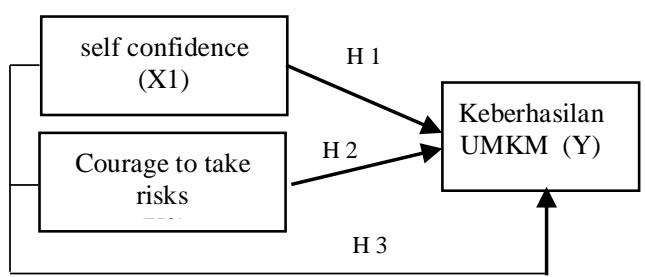

Gambar 1

Framework Penelitian

\section{Hipotesis}

H1. Pengaruh self confidence mempengaruhi keberhasilan UMKM Pemilik Usaha kuliner rendang yang tergabung di Koperasi Iko Sero Payakumbuh.

H2. pengaruh Courage to Take Risks mempengaruhi keberhasilan UMKM Pemilik Usaha kuliner rendang yang tergabung di Koperasi Iko Sero Payakumbuh

H3. pengaruh self confidence dan Courage to Take Risks mempengaruhi keberhasilan UMKM Pemilik Usaha kuliner rendang yang tergabung di Koperasi Iko Sero Payakumbuh.

\section{METODE PENELITIAN}

Penelitian ini dirancang sebagai penelitian kuantitatif. Data yang digunakan dalam penelitian ini dikumpulkan dari UMKM Pemilik Usaha kuliner rendang yang tergabung di Koperasi Iko Sero Payakumbuh. Jenis data dalam penelitian ini terdiri dari data primer dan data sekunder. Data primer diperoleh melalui kuesioner dan wawancara langsung dengan responden mengenai kepercayaan diri, keberanian mengambil risiko, dan kesuksesan wirausaha. Sedangkan data sekunder diperoleh dari pengelola Koperasi Iko Sero Kota Payakumbuh serta data berupa dokumentasi yang berkaitan dengan permasalahan penelitian ini.

Populasi dalam penelitian ini melibatkan seluruh UMKM Pemilik Usaha kuliner rendang yang tergabung di Koperasi Iko Sero Payakumbuh yang berjumlah 43 pelaku usaha yang bergerak pada sentra masakan rendang yang tergabung dalam Koperasi Iko Sero Payakumbuh pada tahun 2021. Karakteristik populasi penelitian ini meliputi seluruh pelaku usaha yang bergerak pada sentra masakan rendang yang tergabung dalam Koperasi Iko Sero Payakumbuh yang secara aktif dan resmi 
diakui oleh Koperasi Iko Sero Payakumbuh, yang dibuktikan dengan adanya bukti menjadi anggota koperasi yang terdaftar secara resmi. Pengambilan sampel dilakukan dengan menggunakan Teknik total sampling dimana semua populasi dalam penelitian ini dijadikan sebagia responden. Jumlah sampel dalam penelitian ini adalah sebanyak 43 responden. Teknik analisis data yang digunakan dalam penelitian ini adalah analisis regresi linier berganda dengan bantuan program SPSS versi 21.

\section{HASIL DAN PEMBAHASAN}

Koperasi Iko Sero terletak di Kota Payakumbuh Provinsi Sumatera Barat yang merupakan sebuah Koperasi yang menaungi UMKM atau pelaku usaha yang bergerak di sektor kuliner yaitu makanan khas Sumatera Barat yaitu Rendang.

Koperasi ini berdiri pada tahun 2019, Koperasi ini memiliki tujuan untuk menjaring atau menjangkau pasarpasar Internasional yang menjadi tujuan eksternal dari Koperasi Iko Sero, sedangkan tujuan internal dari Koperasi Iko sero ini adalah permberdayaan anggota Koperasi berupa support dari sarana yang disediakan pemerintah, bahan baku yang murah, akses informasi dan pelatihan yang diberikan kepada semua anggota yang tergabung di Koperasi Iko Sero.

Koperasi Iko Sero memiliki berbagai macam olahan masakan rendang, yang biasanya masakan rendang hanya diolah menggunakan bahan baku utama daging, dan sekarang Koperasi Iko Sero memberikan sentuhan baru untuk mengolah masakan rendang seperti Rendang Jamur, Rendang Suwir dan Pasta Rendang. Inovasi olahan Pasta Rendang ini di persiapkan untuk menjangkau pasar ekspor untuk beberapa Negara yang memiliki regulasi tidak mengizinkan impor makanan berbahan baku daging dari Negara lain separti Arab Saudi.

\section{Profil responden}

Dari hasil penelitian tentang karakteristik responden berdasarkan jenis kelamin dapat dilihat dari tabel 3 di bawah bahwa persentase pengelompokkan reponden berdasarkan jenis kelamin dimana persentase terbesar yaitu responden yang berjenis kelamin laki-laki dengan persentase $65,11 \%$. Hal ini dikarenakan usaha yang tergabung di Koperasi Iko Sero banyak dipimpin oleh laki-laki walaupun dalam pengerjaan pengolahan produknya tetap menggunakan karyawan perempuan untuk pembuatan produk masakan rendang.

Data profil responden Pada table 3 juga menunjukkan bahwa persentase pengelompokkan reponden berdasarkan pendapatan dimana persentase terbesar yaitu anggota yang memiliki pendapatan Rp3.000.000 - Rp4.000.000 adalah sebanyak 18 orang dengan persentase $41,86 \%$, ini dikarenakan produk yang sediakan oleh $41,86 \%$ dari keseluruhan anggota lebih banyak memiliki inovasi produk, sehingga menarik perhatian pelanggan untuk membeli produk tersebut, sedangkan persentase terendah yaitu anggota koperasi yang memiliki pendapatan Rp1.000.000 - Rp2.000.000 dengan persentase 4,65\%, ini disebabkan produk yang dihasilkan oleh $4,65 \%$ tidak memiliki varian rendang yang beragam.

Hasil penelitian menunjukkan bahwa persentase pengelompokan responden berdasarkan lama usaha berjalan yaitubdimana persentase terbesar pada responden yang usahannya sudah berjalan 3 tahun dengan persentase sebesar $44,18 \%$ sedangkan persentase terendah yaitu responden yang usahanya sudah berjalan $<1$ tahun dengan presentase $4,65 \%$. Hal ini disebabkan karena awal berdirinya 
Koperasi Iko Sero yaitu pada tahun 2019 dan anggota yang memiliki masa yang paling lama dalam menjalankan usahanya adalah anggota yang sudah tergabung dari awal pembentukan KoperasiiniTabel 3

Profil Responden

\begin{tabular}{llll}
\hline No & Keterangan & $\begin{array}{l}\text { Jumlah } \\
(\text { Orang })\end{array}$ & Persentase \\
\hline Umur & & & \\
1 & Laki-laki & 28 & $65,11 \%$ \\
2 & Perempuan & 15 & $34,88 \%$ \\
\hline Pendapatan & & \\
\hline 3 & 1 juta -2 juta & 2 & $4,65 \%$ \\
4 & 2 juta -3 juta & 7 & $16,27 \%$ \\
5 & 3 juta -4 juta & 18 & $41,86 \%$ \\
6 & $>4$ juta & 16 & $37,20 \%$ \\
\hline Lama Usaha Berjalan & & $4,65 \%$ \\
\hline 7 & $<1$ Tahun & 2 & $16,27 \%$ \\
8 & 1 Tahun & 7 & $34,88 \%$ \\
9 & 2 Tahun & 15 & $44,18 \%$ \\
10 & 3 Tahun & 19 & \\
\hline
\end{tabular}

Sumber: Data Primer 2021 (Diolah)

\section{Uji Validitas}

Instrumen penelitian peneliti valid berdasarkan nilai korelasi itemtotal terkoreksi dengan baik. Nilai ini baik karena memiliki nilai diatas 0,3 atau sedikit toleransi diatas 0,25 (Bougie \& Sekaran, 2016). Korelasi item-total yang dikoreksi adalah salah satu parameter aset psikometrik tingkat item. Namun, nilai-nilai tersebut tidak termasuk parameter yang secara khusus mendukung validitas dan bahkan tidak termasuk dalam pembuktian validitas dalam konsep validitas saat ini (Watson, 2015). Korelasi item-total terkoreksi merupakan hasil analisis yang dilakukan oleh Statistical Package for the Social Sciences (SPSS). Korelasi item-total terkoreksi diturunkan dari nilai korelasi item-total tetap. Titik perbaikannya adalah untuk menghilangkan efek tumpang tindih item yang salah, korelasi total adalah nilai korelasi antara skor item dan skor total skala. Prinsipnya adalah korelasi atau lebih spesifiknya korelasi menggunakan momen produk Pearson. Artinya ketika suatu item dikorelasikan dengan skor keseluruhan pada skala tersebut, maka dapat dikatakan bahwa item tersebut mengukur sesuatu secara paralel. Kata pada baris berbeda dengan kata eksak, korelasi item-total terkoreksi merupakan salah satu parameter yang bertujuan untuk melihat kecocokan fungsi item dengan fungsi skala secara keseluruhan. Semakin tinggi nilai korelasi berarti alat tersebut memiliki keserasian atau konsistensi pada skala. Seperti yang ditunjukkan pada Tabel 4, untuk uji validitas yang menunjukkan korelasi total item yang dikoreksi kurang dari 0,3 , maka korelasinya lemah dan peneliti harus menghapus item tersebut. Dalam hal ini, peneliti dapat meninjau item (Hazzi \& Maldaon, 2015). Dalam hal ini semua item pernyataan memiliki nilai lebih dari 0,3 .

\section{Tabel 4}

\section{Uji validitas}

\begin{tabular}{|c|c|c|c|c|}
\hline No & Pernyataan/Indikator & $\begin{array}{l}\text { Correction } \\
\text { item Total } \\
\text { Correlation } \\
\end{array}$ & $\begin{array}{l}\text { Cut } \\
\text { Off }\end{array}$ & Ket \\
\hline & Self Confidence & & & \\
\hline 1. & $\begin{array}{l}\text { Saya memiliki kejelasan } \\
\text { dalam menjalankan usaha } \\
\text { saya }\end{array}$ & 0,391 & 0,30 & Valid \\
\hline 2. & \begin{tabular}{lr}
\multicolumn{2}{c}{ Saya memiliki keyakinan } \\
yang kuat untuk \\
mengembangkan & usaha \\
saya &
\end{tabular} & 0,396 & 0,30 & Valid \\
\hline 3. & $\begin{array}{l}\text { Saya memiliki komitmen } \\
\text { yang kuat dalam } \\
\text { menjalankan usaha agar } \\
\text { mencapai keberhasilan }\end{array}$ & 0,551 & 0,30 & Valid \\
\hline \multirow[t]{2}{*}{4.} & $\begin{array}{ll}\text { Saya konsisten } & \text { dalam } \\
\text { mencapai target } & \text { dalam } \\
\text { mengembangkan } & \text { usaha } \\
\text { saya } & \\
\end{array}$ & 0,592 & 0,30 & Valid \\
\hline & Courage To Take Risks & & & \\
\hline 1. & $\begin{array}{l}\text { Saya berani mengambil } \\
\text { resiko demi mencapai } \\
\text { tujuan usaha saya }\end{array}$ & 0,458 & 0,30 & Valid \\
\hline 2. & $\begin{array}{l}\text { Saya termasuk pribadian } \\
\text { yang suka tantangan } \\
\text { dalam menjalankan usaha } \\
\text { saya }\end{array}$ & 0,381 & 0,30 & Valid \\
\hline 3. & $\begin{array}{l}\text { Saya memiliki sifat yang } \\
\text { sabar dalam menjalankan } \\
\text { usaha saya }\end{array}$ & 0,345 & 0,30 & Valid \\
\hline 4. & $\begin{array}{l}\text { Saya adalah orang yang } \\
\text { pantang menyerah dalam } \\
\text { menjalankan bisnis atau } \\
\text { usaha }\end{array}$ & 0,442 & 0,30 & Valid \\
\hline
\end{tabular}




\begin{tabular}{|c|c|c|c|c|}
\hline & Variabel Keberhasilan & & & \\
\hline 1. & $\begin{array}{lr}\text { Penjualan } & \text { saya } \\
\text { mengalami peningkatan } \\
\text { setiap bulannya }\end{array}$ & 0,450 & 0,30 & Valid \\
\hline 2. & $\begin{array}{l}\text { Saya merasakan bahwa } \\
\text { produksi usaha ini } \\
\text { mengalami peningkatan }\end{array}$ & 0,549 & 0,30 & Valid \\
\hline 3. & $\begin{array}{l}\text { Saya merasakn usaha } \\
\text { saya } \\
\text { peningkatan } \\
\text { laba }\end{array}$ & 0,527 & 0,30 & Valid \\
\hline 4. & $\begin{array}{l}\text { Usaha saya mengalami } \\
\text { pertumbuhan yang baik }\end{array}$ & 0,528 & 0,30 & Valid \\
\hline 5. & $\begin{array}{l}\text { Usaha saya berkembang } \\
\text { dengan cepat dan sesuai } \\
\text { dengan tujuan usaha }\end{array}$ & 0,645 & 0,30 & Valid \\
\hline
\end{tabular}

\section{Uji Reliabilitas}

Para peneliti telah menemukan, dengan meninjau literatur, bahwa Cronbach paling sering digunakan di banyak disiplin ilmu, terutama ketika studi membahas beberapa skala Likert dalam penelitian psikologi industri dan sosial. Dengan kata lain, Cronbach's Alpha adalah ukuran konsistensi internal sebuah skala, yang menggambarkan sejauh mana semua item skala mengukur konstruksi yang sama. Sebagai aturan praktis,> 0,9: Sangat Baik,> 0,8: Baik,> 0,7: Dapat Diterima,> 0,6: Diragukan,> 0,5: Tidak Baik, sedangkan <0,5: Tidak Dapat Diterima (Hazzi \& Maldaon, 2015).

Dari tabel 5 dibawah ini dapat diketahui bahwa variabel Self Confidence, Courage to Take Risks dan Keberhasilan UMKM memiliki nilai reliabilitas diatas 0,6 yaitu dapat diterima dan dinyatakan reliabel. Reliabilitas adalah keakuratan suatu alat ukur yang mengacu pada derajat konsistensi antara berbagai pengukuran suatu variabel (Hair et al., 2019).

Tabel 5

Uji validitas

\begin{tabular}{lllll}
\hline No & Variabel & $\begin{array}{c}\text { Cronbach's } \\
\text { Alpha }\end{array}$ & Cut Off & Keterangan \\
\hline 1. & $\begin{array}{l}\text { Self confidence } \\
\text { (X1) }\end{array}$ & 0,620 & 0,60 & Reliabel \\
2. & $\begin{array}{l}\text { Courage to } \\
\text { take risks (X2) }\end{array}$ & 0,641 & 0,60 & Reliabel \\
3. & $\begin{array}{l}\text { Keberhasilan } \\
(\mathrm{Y})\end{array}$ & 0,672 & 0,60 & Reliabel \\
\hline
\end{tabular}

\begin{tabular}{cccccc} 
Hasil pengujian Hipotesis \\
Tabel 6 \\
Hasil Uji t \\
\hline \multirow{3}{*}{ Model } & $\begin{array}{c}\text { Unstandarized } \\
\text { Coefficients }\end{array}$ & $\begin{array}{l}\text { Standardized } \\
\text { Coefficients }\end{array}$ & t & Sig. \\
\cline { 2 - 4 } & $\mathbf{B}$ & $\begin{array}{c}\text { Std. } \\
\text { Error }\end{array}$ & Beta & & \\
\hline 1 & 1.220 & 1.392 & & 2.452 & .019 \\
\hline $\begin{array}{c}\text { (Constant) } \\
\text { self } \\
\text { confidence } \\
\text { courage to } \\
\text { take risks }\end{array}$ & .439 & .222 & .299 & 2.973 & .000 \\
\hline
\end{tabular}

Berdasarkan tabel 6 di atas, nilai signifikansi dari variabel self confidence adalah $0,000<0,05$ dan nilai t-hitung nya $2,973>$ t-tabel nya 1,683 . Dari hasil tersebut dapat disimpulkan bahwa variabel self confidence mempunyai pengaruh positif dan signifikan terhdap keberhasilan UMKM

dan untuk hipotesis kedua terdapat nilai signifikansi dari variabel Courage to take risks adalah $0,001<0,05$ dan nilai t-hitung nya 2,044 > t-tabel nya 1,683 . Dari hasil tersebut dapat disimpulkan bahwa variabel Courage to take risks mempunyai pengaruh positif dan signifikan terhadap keberhasilan.

Tabel 7

Hasil Uji F

\begin{tabular}{lrrrrrr}
\hline \multicolumn{2}{l}{ Model } & $\begin{array}{c}\text { Sum of } \\
\text { Squares }\end{array}$ & Df & Square & F & Sig. \\
\hline 1 & Regression & 33.009 & 2 & 16.505 & 11.955 & $.000^{\mathrm{b}}$ \\
& Residual & 337.735 & 40 & 8.443 & & \\
\multicolumn{1}{l}{ Total } & 370.744 & 42 & & & \\
\hline
\end{tabular}

a. Dependent Variable: Keberhasilan

b. Predictors: (Constant), Courage to take risks, self confidence

Hasil Uji Koefisien Determinasi

Tabel 8

Uji Koefisien Determinasi

Model Summary ${ }^{\mathrm{b}}$

\begin{tabular}{lllll}
\hline Model & $\mathbf{R}$ & R Square & $\begin{array}{l}\text { Adjusted } \\
\text { Square }\end{array}$ & $\begin{array}{c}\text { R } \\
\begin{array}{l}\text { Std. Error of } \\
\text { the Estimate }\end{array}\end{array}$ \\
\hline 1 & $.398^{\mathrm{a}}$ & .489 & .443 & 2.90575 \\
\hline a. Predictors: (Constant), Courage to take risks, self confidence \\
b. Dependent Variable: Keberhasilan \\
\multicolumn{5}{c}{ Pada tabel $8 \mathrm{di}$ atas menunjukkan }
\end{tabular}

bahwa nilai koefisien Adjusted $R$ Square adalah sebesar 0,443 hal ini berarti $44,3 \%$ variabel keberhasilan dapat 
dijelaskan oleh variabel self confidence dan Courage to take risks, sedangkan sisanya $(100 \%-44,3 \%=55,7 \%)$ dipengaruhi oleh variabel lain yang tidak ada di dalam penelitian ini seperti modal, jumlah tenaga kerja, tingkat pendidikan dan pengalaman menjalankan usaha.

\section{Pengaruh self confidence Terhadap Keberhasilan}

Dari hasil penelitian diatas menunjukkan bahwa variabel self confidence memiliki nilai signifikan $0,000<0,05$ dan nilai t-hitung nya 2,973 $>\mathrm{t}$-tabel nya 1,683. Dari hasil tersebut dapat disimpulkan bahwa variabel self confidence mempunyai pengaruh positif dan signifikan terhdap keberhasilan. Memperhatikan hasil uji t test ini, maka hipotesis 1 yang menyatakan bahwa self confidence mempunyai pengaruh positif dan signifikan terhadap keberhasilan dapat diterima.

Hal ini menunjukkan bahwa kepercayaan pelaku usaha yang tergabung di Koperasi Iko Sero akan memberikan suatu nilai bagi keberhasilan usaha yang dijalankan. Seperti pernyataan dari pelaku usaha yaitu Saya memiliki keyakinan yang kuat untuk mengembangkan usaha saya, yaitu dengan persentasi $85,11 \%$ berdasarkan nilai TCR tersebut dapat membuktikan bahwa pernyataan tersebut banyak disetujui oleh responden, maka dapat mempengaruhi keberhasilan usaha yang di jalankan.

Hasil penelitian ini selaras dengan penelitian yang dilakukan oleh DS \& Trimeiningrum, (2018) hasil penelitianya membuktikan bahwa self confidence memiliki pengaruh positif dan signifikan terhadap keberhasilan dan penelitian yang dilakukan oleh Yuseima, (2018) juga menujukan hasil penelitian bahwa self confidence mempunyai pengaruh positif dan signifikan terhadap keberhasilan.
Temuan penelitian ini menunjukkan bahwa keberanian mengambil risiko merupakan variabel bebas yang berpengaruh positfi dan paling kecil terhadap Kesuksesan UMKM. Proses kewirausahaan melibatkan keadaan ketidakpastian tentang kesejahteraan finansial, kesejahteraan psikologis, keamanan karir, dan hubungan keluarga. Dalam situasi ini, pengusaha dengan kecenderungan pengambilan risiko yang lebih rendah dapat mengharapkan tingkat kinerja yang lebih tinggi dalam aktivitas kewirausahaan karena mereka cenderung mengambil pendekatan berisiko untuk menjalankan bisnis mereka dalam hal perolehan sumber daya, strategi, dan organisasi (Ahmad, Musa, Widhi, \& Tahmir, (2018). Berbeda dengan penelitian yang peneliti hasilkan bahwa Beberapa studi empiris telah memberikan bukti bahwa kecenderungan pengambilan risiko tampaknya berhubungan negatif dengan keberlanjutan bisnis. Temuan penelitian ini sejalan dengan penelitian Begley dan Boyd (1987) yang menemukan bahwa Return on Assets (ROA) dari 147 usaha kecil menurun karena kecenderungan untuk mengambil risiko yang berlebihan. Miner et al (1989), yang melakukan survei terhadap 118 pengusaha teknis, menunjukkan bahwa rata-rata pertumbuhan penjualan tahunan berhubungan positif dengan kecenderungan mereka untuk menghindari risiko. Forlani dan Mullins (2000) melakukan percobaan dengan 78 eksekutif perusahaan baru yang tumbuh cepat dan menemukan bahwa pengusaha lebih menyukai bisnis berisiko rendah daripada bisnis berisiko tinggi.

\section{Pengaruh Courage to take risks Terhadap Keberhasilan}

Hasil uji-t dari variabel Courage to take risks yaitu nilai signifikansi dari variabel Courage to take risks adalah $0,001<0,05$ dan nilai t-hitung nya 2,044 
$>$ t-tabel nya 1,683. Dari hasil tersebut dapat disimpulkan bahwa variabel Courage to take risks mempunyai pengaruh positif dan signifikan terhadap keberhasilan. Memperhatikan hasil uji t test ini, maka hipotesis 2 yang menyatakan bahwa Courage to take risks mempunyai pengaruh positif dan signifikan terhadap keberhasilan dapat diterima.

Adanya pengaruh Courage to take risks terhadap keberhasilan disebabkan karena Courage to take risks merupakan suatu faktor bagi seseorang pelaku usaha untuk mencapai keberhasilan dalam menjalankan usahanya, Nilai TCR tertinggi dalam variabel ini yaitu Saya adalah orang yang pantang menyerah dalam menjalankan bisnis atau usaha, yaitu dengan persentasi $85,58 \%$ merupakan pernyataan yang banyak disetujui responden dan akan mempengaruhi keberhasilan usaha.

Hasil penelitian ini selaras dengan penelitian yang dilakukan oleh Wulandari, \& Deliabilda, (2020) dengan hasil penelitian bahwa Courage to take risks mempunyai pengaruh positif dan signifikan terhadap keberhasilan dan penelitian yang dilakukan oleh DS \& Trimeiningrum, (2018) yang juga menujukan hasil penelitian bahwa Courage to take risks mempunyai pengaruh positif dan signifikan terhadap keberhasilan.

\section{Pengaruh self confidence dan Courage to take risks Terhadap Keberhasilan}

Berdasarkan hasil Uji F Ketika variable ini diuji secara simultan diaman hasilnya menyatakan bahwa variable pengaruh diri dan keberanian mengambil resiko memiliki pengaruh yang siginifikan terhadap keberhasilan UMKM kuliner di kota Payakumbuh dengan nilai signifikansi sebesar 0,000 $<$ jika dibandungkan dengan nilai sig 0,05 .

\section{SIMPULAN}

Self confidence dan Courage to take risks berpengaruh positif dan signifikan terhadap keberhasilan usaha UMKM dibidang Gastronomi rendang pada Koperasi Iko Sero Kota payakumbuh. Kontribusi self confidence dan keberanian mengambil risiko, terhadap keberhasilan UMKM rendang $44,3 \%$. Self confidence memiliki pengaruh paling signifikan terhadap keberhasilan UMKM dibandingkan dengan variabel keberanian mengambil risiko.

\section{UCAPAN TERIMAKASIH}

Peneliti mengucapkan terimakasih kepada seluruh manajamen dan anggota Koperasi Iko Sero Kota Payakumbuh yang telah bersedia mendukung dan bekerjasama dalam membantu serta memberikan data maupun informasi untuk tujuan penelitian ini.

\section{DAFTAR PUSTAKA}

Ahmad, M. I. S., Musa, C. I., Widhi, A., \& Tahmir, S. (2018) The Influence of Achievement Motivation, Courage To Take Risks, And Entrepreneurial Commitment On Business Sustainability of Local Market Traders In Makassar City.

Anthony. (2017). Effects Of Discipline Management On Employee. Jakarta: Bina Aksara.

Azima, F., \& Sayuti, K. (2016). The evaluation of nutritional value of Rendang

Minangkabau. Agriculture and Agricultural Science Procedia, 9, 335-341.

Begley, T. M., \& Boyd, D. P. 1987. A comparison of entrepreneurs and managers of small business firms. Journal of Management, 13, 99-108. 
Bougie, R., \& Sekaran, U. (2016). Research Methods For Business: A Skill Building 7 ed. Wily.

Dinas Koperasi dan UKM Kota Payakumbuh, 2018. Perkembangan Jumlah Usaha di Kota Payakumbuh tahun 20142018.

DS, G. O., \& Trimeiningrum, E. (2018). Pengaruh Percaya Diri Dan Keberanian Mengambil Risiko Terhadap Keberhasilan Usaha Pada Umkm Makanan Ringan Di Kota Semarang; Studi Kasus Pada Sentra Industri Kerupuk, Keripik, Peyek dan Sejenisnya di Kota Semarang. Jurnal Ekonomi, Manajemen Akuntansi dan Perpajakan (Jemap), 1(1), 26-40.

Fatoki, O. (2018). The impact of entrepreneurial resilience on the success of small and medium enterprises in South Africa. Sustainability, 10(7), 2527.

Forlani, D., \& Mullins, J. W. 2000. Perceived Risks and Choices in Entrepreneurs' New Venture Decisions. Journal of Business Venturing 15, 305-322.

Furue, N., Ab Aziz, Y., Mori, K., Anitawati Hermawan, A., Assarut, N., Uehara, W., \& Washida, Y. (2020). Low-Risk Innovative Ideas with High Self-Confidence: Innovation Process Characteristics in ASEAN Countries. International Journal of Innovation and Technology Management, 17(02), 2050012.

Garaika, G., Margahana, H. M., \& Negara, S. T. (2019). Self efficacy, self personality and self confidence on entrepreneurial intention: study on young enterprises. Journal of Entrepreneurship Education, 22(1), 1-12.

Gufron. (2017). Teori - teori Psikologi.
Yogyakarta : Ar-ruzz Media.

Hair, J. F., Hult, G. T. M., Ringle, C. M., Sarstedt, M., Castillo Apraiz, J., Cepeda Carrión, G., \& Roldán, J. L. (2019). Manual de partial least squares structural equation modeling (pls-sem). OmniaScience Scholar.

Hakim. (2016). Mengatasi Rasa Tidak Percaya Diri. Jakarta: Puspa Swara.

Hazzi, O., \& Maldaon, I. (2015). A pilot study: Vital methodological issues. Business: Theory and Practice, 16(1), 53-62.

Hidayat. (2016). Pengaruh Konsep Diri dan Kepercayaan Diri Terhadap Perilaku Konsumtif Pembelian Konsumen. Bandung : Alfabeta.

Hjalager, A. M., \& Richards, G. (Eds.). (2003). Tourism and gastronomy. Routledge.

innovative firms. Journal of Applied Psychology, 74, 554560.

Jadmiko, P., Azliyanti, E., \& Putri, T. D. (2019). Linking Perceived Educational Support to Entrepreneur Intention: The Mediating Effect of SelfConfidence. AMAR (Andalas Management Review), 3(1), 1-17.

Júnior, C. H., Spers, E. E., de Lima, L. M., da Costa Simões, D., \& Neves, M. F. (2021). Brazilian farmer confidence in business performance. International Food and Agribusiness Management Review, 1-18.

Kozubíková, L., Dvorský, J., Cepel, M., \& Balcerzak, A. P. (2017). Important characteristics of an entrepreneur in relation to risk taking: Czech Republic case study. Journal of International Studies.

Miner, J. B., Smith, N. R., \& Bracker, J. S. 1989. Role of entrepreneurial 
task motivation in the growth of technologically

Otache, I. (2020). Applying the theory of planned behaviour to hospitality management students in Nigeria: the mediating role of selfconfidence. Journal of Enterprising Communities: People and Places in the Global Economy.

Ranto. (2017). Analisis Hubungan Antara Motivasi, Pengetahuan kewirausahaan dan Kemandirian Usaha Terhadap Kinerja Pengusaha. Bandung: Alfabeta.

Suryana. (2017). Kewirausahaan Pedoman Praktis Kiat dan Proses Menuju Sukses. Jakarta: Salemba Empat.

Tracy. (2016). Motivation (The Brian Tracy Success Library). Bandung : Alfabeta.

Watson, R. (2015). Quantitative research. Nursing standard (Royal College of Nursing (Great Britain)

Willis. (2017). Konseling Individual Teori dan Praktek. Bandung : Alfabeta.

Wulandari, A., \& Deliabilda, S. A. (2020). Keberanian Mengambil Risiko Bisnis pada Mahasiswa Ekonomi dan Bisnis. Jurnal Pengembangan Wiraswasta, 22(3), 217.

Yuseima, D. (2018). Pengaruh Efikasi Diri Dan Motivasi Usaha Terhadap Keberhasilan Usaha Pada Pengrajin Boneka Di Cijerah Bandung (Doctoral dissertation, Universitas Komputer Indonesia).

Yusuf, A. M. (2020, December). Exploration of Students' Self Confidence Entrepreneurship Based on Minangkabau Culture in UIN Imam Bonjol Padang. In 2nd International Conference Innovation in Education (ICoIE
2020) (pp. 404-407). Atlantis Press. 